ORİJINAL MAKALE / ORIGINAL ARTICLE

Balıkesir Sağlık Bilimleri Dergisi / BAUN Să̆ Bil Derg

Balıkesir Health Sciences Journal / BAUN Health Sci J

ISSN: 2146-9601- e ISSN: 2147-2238

Doi: https://doi.org/10.53424/balikesirsbd.978173

\title{
Yoksul Kadınların Meme Kanserine Yönelik İnançlarının Mamografi Yaptırma Davranıșlarına Etkisinin İncelenmesi
}

\section{Sevgi GÜÇLÜ DEMİRTAŞ 國, Nihal GÖRDES AYDOĞDU ${ }^{2}$}

${ }^{1}$ Ege Üniversitesi Hastanesi

${ }^{2}$ Erzurum Teknik Üniversitesi, Sağlık Bilimleri Fakültesi, Halk Sağlığı Hemşireliği Anabilim Dalı

\begin{abstract}
Geliş Tarihi / Received: 03.08.2021, Kabul Tarihi / Accepted: 08.10.2021
ÖZ

Amaç: Bu çalışma yoksul kadınların meme kanserine yönelik inançlarının mamografi yaptırma davranışları üzerine etkisinin incelenmesi amacıyla yapılmıştır. Gereç ve Yöntem: Tanımlayıcı tipte olan araştırma Ocak 2017-Temmuz 2019 tarihleri arasında İzmir Bornova ilçesi’nde yürütülmüştür. Çalışmanın örneklemini basit rastgele yöntemle seçilen toplam 384 kadın oluşturmaktadır. Veriler Sosyo-Demografik Özellikler Bilgi Formu, Sağlık İnanç Modeli Ölçeği ve Mamografi Yeterlilik Ölçeği ile toplanmıştır. Verilerin analizinde; tanımlayıcı istatistikler, ki-kare testi, iki ortalama arasındaki farkın önemlilik testi ve lojistik regresyon analizi kullanılmıştır. Bulgular: Kadınların \%26.3'ü düzenli mamografi çektirirken, düzenli mamografi çektirmeyenlerin oranı \% 73.7 'dir. Çalışmaya katılan kadınların yaş, eğitim, sosyal güvence ile mamografi yaptırma durumları arasında istatistiksel olarak anlamlı fark saptanmıştır. Medeni durum ile mamografi yaptırma durumları arasında istatistiksel olarak anlamlı fark yoktur. Yapılan lojistik regresyon analizinde eğitim seviyesinin artmasının mamografi yaptırma oranını 5.12 kat arttırdığı saptanmıştır. Kadınların Sağlık İnanç Modeli Ölçeği alt boyut puan ortalamaları (duyarlılık, ciddiyet, sağlık motivasyonu, yarar, engel) ve Mamografi Yeterlilik Ölçeği puan ortalamaları ile mamografi yaptırma durumları arasında istatistiksel olarak anlamlı fark vardır $(\mathrm{p}<0.05)$. Sağlık motivasyonu algısı ile mamografi engel algısının kadınlarda mamografi yaptırma davranışını sırasıyla 0.85 ve 0.92 kat arttırdığı saptanmıştır. Sonuç: Bu çalışma sonucunda yoksul kadınlarda mamografi yaptırma oranının düşük olduğu saptanmıştır. Sağlık hizmetlerinin sunumunda yoksul kadınlara daha fazla öncelik verilmesi önerilmektedir.
\end{abstract}

Anahtar Kelimeler: Yoksulluk, Erken Tanı Davranışı, Sağlık İnanç Modeli.

\section{The Effects of Low-Income Women's Belief of Breast Cancer on Mammographic Making} Behaviors

\begin{abstract}
Objective: The study was conducted to investigate the effects of poor women's breast cancer beliefs on mammography behaviors. Material and Methods: This descriptive study was carried out in the Bornova, İzmir. The sample of the study consisted of 384 women selected by simple random method. The data were collected to Socio Demographic Characteristics Information Form, Health Belief Model Scale and Mammography Sufficiency Scale. In the analysis of data; descriptive statistics, chi square test, significance test of difference between two means and logistic regression analysis were used. Results: While $26.3 \%$ of women had regular mammography, the rate of those who did not undergo regular mammography was $73.7 \%$. A statistically significant difference was found between age, education, social security and mammography status of the women participating in the study. There was no statistically significant difference between marital status and mammography. In the logistic regression analysis, it was found that the increase in the level of education increased the mammography rate by 5.12 times. There is a statistically significant difference between women's Health Belief Model Scale sub-scale mean scores (sensitivity, severity, health motivation, benefit, obstacle) and mammography competence scale and mean mammography $(\mathrm{p}<0.05)$. The perception of health motivation and the perception of mammography were found to increase the mammography behaviors in women by 0.85 and 0.92 fold, respectively. Conclusion: As a result, it was found that the rate of having mammography in poor women was low. It is recommended to give more priority to poor women in the provision of health services.
\end{abstract}

Keywords: Poverty, Early Diagnosis Behavior, Health Belief Model.

Sorumlu Yazar / Corresponding Author: Nihal GÖRDES AYDOĞDU, Erzurum Teknik Üniversitesi, Sağlık Bilimleri Fakültesi, Halk Sağlığ

E-mail: nihal.aydogdu@erzurum.edu.tr

Bu makaleye atıf yapmak için / Cite this article: Güçlü Demirtaş, S., \& Gördes Aydoğdu, N. (2021). Yoksul kadınların meme kanserine yönelik inançlarının mamografi yaptırma davranışlarına etkisinin incelenmesi. Balıkesir Sağlık Bilimleri Dergisi, 10(3):379-385. https://doi.org/10.53424/balikesirsbd.978173

CCopyright 2021 by the Balıkesir Sağlık Bilimleri Dergisi. 


\section{GíRiş}

Dünya'da kadınlar arasında meme kanseri insidansı yüz binde 47.8 ve meme kanserinden ölüm oranları ise 13.6'dır. (Global Cancer Observatory [Globocan], 2020). Türkiye'de kadınlarda en fazla meme kanseri görülmekte olup, insidansı yüz binde 45.6'dır (TC. Sağlık Bakanlığı Halk Sağlığı Genel Müdürlüğü, 2019). Meme kanseri özellikle gelişmiş ülkelerde daha fazla oranda görülmekteyken, gelişmekte olan ülkelerde mortalite oranı erken tanı ve tedavi olanaklarının kısıtlı oluşu nedeniyle daha fazladır. Mamografi, meme kanseri taramalarında altın standarttır ve ülkemizde mamografi ile meme kanseri taramaları genç nüfusta görülme oranlarının artması nedeniyle 50'den 40'a düşürülmüştür (Sağlık Bakanlığı, 2018).

Dünyada ve ülkemizde farklı sosyo-ekonomik ve kültürel özelliklere sahip bireylerde yürütülen çalışmalar kadınların mamografi çektirme oranlarının düşük olduğunu ve bu oranın yoksul kadınlarda daha da düştüğünü belirtmektedir (Açıkgöz, Çehreli ve Ellidokuz, 2015; Gathirua-Mwangi, 2018; Güzel ve Bayraktar, 2019; Subramanian, Oranye, Masri, Taib ve Ahmad, 2013; Vang, Margolies ve Jandorf, 2018). Yoksulluk ve sağlık birbiri ile yakından ilişkili iki kavramdır. Dünya Sağlık Örgütü'ne (DSÖ) göre hastalık ve ölümleri en önemli nedeni yoksulluktur ve sağlığ koruma, geliştirme davranışlarını olumsuz yönde etkilemektedir. Cinsiyet yoksulluk açısından belirleyici bir faktör olması nedeniyle kadınlar, yoksulluk sağlık ilişkisinin etkilerinin en fazla görüldüğ̈̈ gruptur. Bu nedenle özellikle erken tanı davranışlarının geliştirilmesinde öncelikli gruplar arasındadir (Kocabacak, 2014).

Türkiye'de kadınların erken tanıya yönelik davranışları yetersiz olmakla birlikte, özellikle yoksul kadınların mamografi davranışlarına etki eden etmenlerin incelendiği çalışmalara ulaşılamamıştır. Hemşireler, yoksul kadınların mamografi yaptırma davranışlarını etkileyen faktörlerin belirlenmesine yönelik yapacakları araştırmalarla, meme kanseri erken tanı davranışlarında bulunmalarını engelleyen faktörleri azaltarak tarama programlarının geliştirilmesine katkıda bulunabileceklerdir.

\section{GEREÇ VE YÖNTEM}

\section{Araştırmanın tipi, yeri ve zamanı}

Tanımlayıcı tipte olan çalışma İzmir Bornova ilçesi Doğanlar Mevlana Mahallesi'nde Ocak 2017-Temmuz 2019 tarihleri arasında yürütülmüştür.

\section{Araştırmanın evren ve örneklemi}

Araştırmanın evrenini İzmir ili, Bornova ilçesi, sosyoekonomik düzeyi düşük bir bölge olan Doğanlar Mevlana mahallesinde yaşayan 40-69 yaş grubu yoksul kadınlar oluşturmuştur. Çalışmada yoksul bireyler 'mutlak yoksulluk ölçümü' yapılarak belirlenmiştir. Gıda kalori yaklaşımını temel alan bu hesaplamada; Dünya Sağlık Örgütü tarafindan belirlenen 2400 kalori günlük kalori ihtiyacı olarak temel alınmıştır. Buna göre ilk önce temel besinler tablosunda yer alan gidaların birim fiyatları yerel marketlerden çıkarılmıştır. Ardından bu gıdaları temin edebilmek için dört kişilik bir ailenin aylık harcaması hesaplanarak yoksulluk sınırı belirlenmiştir. Ailedeki yetişkin sayısı dörtten az veya çok olması durumuna göre basit orantı yöntemi ile yoksulluk belirlemesi yapılmıştır. Gelir durumu 4 kişilik bir ailede aylık 980.720,00 TL ve altında olan kadınlar çalışmaya alınmıştır. Örneklem büyüklüğü evreni belli olmayan örneklem büyüklüğü hesaplama formülü kullanılarak hesaplanmıştır ve 384 yoksul kadın çalışmaya dahil edilmiştir. Çalışmaya katılacak bireylere Bornova Belediyesi'nden sosyal yardım alan kişilerin listesinden rastgele seçilerek ulaşılmıştır. Buna göre 40-69 yaş grubu, memesinde herhangi bir kitlesi ve meme kanseri öyküsü olmayan, çalışmada belirlenen yoksulluk kriterinde olan ve araştırmaya katılmayı kabul eden kadınlar çalışmaya alınmıştır.

\section{Araştırmanın değişkenleri}

Çalışmanın bağımlı değişkeni kadınların düzenli mamografi yaptırma durumudur (iki yılda bir mamografi). Bağımsız değişkenler; katılımcıların yaşı, eğitimi, medeni durumu, sosyal güvence durumu, Sağlık İnanç Modeli Ölçeği algılanan ciddiyet, duyarlılık, sağlık motivasyonu, mamografi yarar, mamografi engel alt boyut puan ve Mamografi Yeterlilik Ölçeği puan ortalamalarıdır.

\section{Veri toplama araçları}

Çalışmanın verileri Tanıtıcı Özellikler Bilgi Formu, Meme Kanseri Taramalarında Sağlık İnanç Modeli Ölçeği ve Mamografi Yeterlilik Ölçeği kullanılarak toplanmıştır.

Tanitıcı Özellikler Bilgi Formu: Araştırıcılar tarafından oluşturulan form, kadınların bazı demografik özellikleri, aylık gelir miktarı, ailede yaşayan birey sayısı ve mamografi yaptırma durumuna yönelik yedi sorudan oluşmaktadır.

Meme Kanseri Taramalarında Sağlık Inanç Modeli Ölçeği: Ölçek Champion tarafından geliştirilmiş olup meme kanseri ve erken tanıya yönelik bireysel algıları ölçmektedir (Gözüm, Karayurt ve Aydın, 2004). Duyarlılık, ciddiyet, yarar, engel, öz etkililik ve sağlık motivasyonu algısı olmak üzere altı alt boyuttan oluşan ölçeğin alt boyut güvenirlik katsayıları 0.60 ile 0.93 arasında değişmektedir. Bu araştırmada Gözüm, Karayurt ve Aydın tarafından (2004) güvenirlik geçerlilik çalışması yapılan ölçeğin duyarlılık, ciddiyet, sağlık motivasyonu, mamografi yararları ve mamografi engelleri alt boyutları kullanılmıştır. Orijinal ölçek toplam 52 maddeden, duyarlılık, ciddiyet, sağlık motivasyonu, mamografi yararları ve mamografi engelleri alt boyutlarını içeren ölçek 30 maddeden oluşmaktadır. Beşli Likert tipindeki ölçeğin genel toplam puanı yoktur. Alt boyutlardan alınan puanın yükselmesi o boyuta ait algının yüksek olduğunu göstermektedir.

$\mathrm{Bu}$ çalışmada ölçek alt boyutları güvenirlik katsayıları; duyarlılık algısı 0.99, ciddiyet algısı 0.99, sağlık motivasyonu algisı 0.98 , mamografi yarar algısı 0.98 ve mamografi engel algısı 0.98 olmak üzere belirlenmiştir.

Mamografi Yeterlilik Ölçeği: Mamografi Yeterlilik Ölçeği bireylerin mamografi yaptırmaya ilişkin öz etkililik algılarını ölçmek amacıyla 2005 yılında Champion ve arkadaşları tarafından geliştirilmiştir. Toplam 10 sorudan oluşan ölçek 5'li Likert tipindedir (kesinlikle katılmıyorum 1-kesinlikle katılıyorum 5). 
Ölçekten alınan puanlar minimum 10 maksimum 50'dir. Yüksek puan mamografi yaptırma olasılığının arttığını göstermektedir. Ölçeğin Cronbach alfa değeri 0.87 olarak saptanmıştır (Champion, Skinner ve Menon, 2005). Ölçek Seçginli tarafında (2012) Türkçe'ye uyarlanmıştır ve Cronbach alfa değeri .90 olarak belirlenmiştir. Bu çalışmada Cronbach alfa değeri 0.969'dur.

Verilerin değerlendirilmesi

Veriler SPSS 16.0 paket programında tanımlayıcı istatistikler, ki-kare, iki ortalama arasındaki farkın önemlilik testi ve lojistik regresyon analizi kullanılarak analiz edilmiştir.

\section{Araştırmanın etik yönü}

Araştırmanın yürütülebilmesi için İzmir ili Bornova Belediyesi'nden ve Dokuz Eylül Üniversitesi Girişimsel Olmayan Klinik Araştırmalar Etik Kurulu'ndan izin alınmıştır (Karar No: 2015/04-02 Tarih: 12.02.2015). Ayrıca çalışmada kullanılan ölçeklerin Türkçe geçerlik güvenirlik çalışmasını yürüten araştırmacılardan ölçek kullanım izni ve araştırmaya katılan bireylerden sözel onam alınmıştır.

\section{BULGULAR}

Çalışmaya alınan kadınların \%36.2'si 40-49 yaş, \%24.7'si 50-59 yaş, \%39.1'i 60-69 yaş grubundadır. Kadınların \%60.2'sininin eğitim seviyesi ilkokul altı, \%80.7'si evli, \%19.3'ü bekardır ve \%85.7'sinin sosyal güvencesi vardır.

Tablo 1. Kadınların mamografi yaptırma durumu $(\mathbf{n}=384)$

\begin{tabular}{|l|r|r|}
\hline $\begin{array}{l}\text { Düzenli mamografi yaptırma } \\
\text { durumu }\end{array}$ & $\mathbf{n}$ & $\boldsymbol{\%}$ \\
\hline Yaptıran & 101 & 26.3 \\
\hline Yaptırmayan & 283 & 73.7 \\
\hline
\end{tabular}

Çalışmaya katılan kadınların düzenli mamografi yaptırma durumları Tablo 1'de yer almaktadır. Katılımcıların \%26.3'ü düzenli mamografi yaptırırken, düzenli mamografi yaptırmayanların oranı \% 73.7 'dir.

Tablo 2. Katılımcıların tanıtıcı özelliklerine göre mamografi yaptırma durumları.

\begin{tabular}{|c|c|c|c|c|c|c|}
\hline \multirow[t]{2}{*}{ Değişkenler } & \multicolumn{2}{|c|}{ Yaptiriyor } & \multicolumn{2}{|c|}{ Yaptirmiyor } & \multirow[t]{3}{*}{$\chi^{2}$} & \multirow[t]{3}{*}{$\mathbf{p}$} \\
\hline & $\mathbf{n}$ & $\%$ & $\mathbf{n}$ & $\%$ & & \\
\hline \multicolumn{5}{|l|}{ Yaş } & & \\
\hline 40-49 yaş arası & 78 & 77.2 & 61 & 21.6 & \multirow[t]{3}{*}{105.68} & \multirow[t]{3}{*}{0.000} \\
\hline 50-59 yaş arası & 17 & 16.8 & 78 & 27.6 & & \\
\hline 60-69 yaş arası & 6 & 5.9 & 144 & 50.9 & & \\
\hline \multicolumn{5}{|l|}{ Ĕgitim } & \multirow[t]{3}{*}{117.35} & \multirow[t]{3}{*}{0.002} \\
\hline İlkokul altı & 15 & 14.9 & 216 & 76.3 & & \\
\hline İlkokul ve üstü & 86 & 85.1 & 67 & 23.7 & & \\
\hline \multicolumn{5}{|l|}{ Medeni durum } & \multirow[b]{3}{*}{2.647} & \multirow[b]{3}{*}{0.104} \\
\hline Evli & 76 & 75.2 & 234 & 82.7 & & \\
\hline Bekar & 25 & 24.8 & 49 & 17.3 & & \\
\hline \multicolumn{5}{|l|}{ Sosyal güvence } & \multirow{4}{*}{19.852} & \multirow{4}{*}{0.000} \\
\hline Var & 100 & 99 & 229 & 80.9 & & \\
\hline Yok & 1 & 1 & 54 & 19.1 & & \\
\hline Toplam & 101 & 100 & 283 & 100 & & \\
\hline \multicolumn{7}{|c|}{ 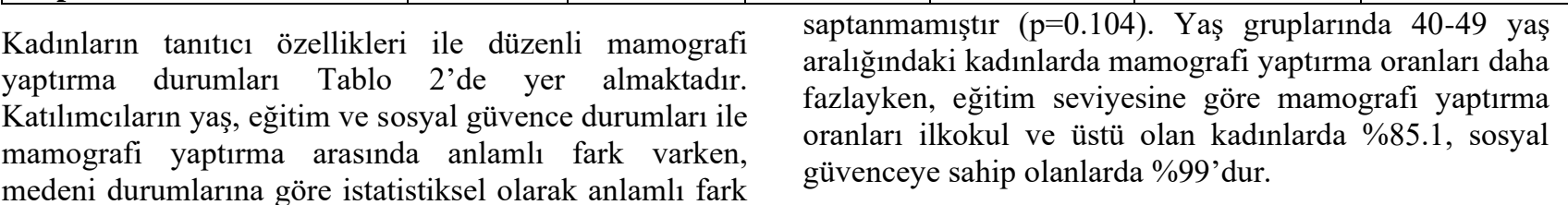 } \\
\hline
\end{tabular}

Tablo 3. Katılımcıların meme kanseri taramalarında Sağlık İnanç Modeli Ölçeği alt boyut ve Mamografi Yeterlilik Ölçeği puan ortalamaları.

\begin{tabular}{|c|c|c|}
\hline Meme Kanseri Taramalarında Sağlık İnanç Modeli Ölçeği alt boyutları & $\mathbf{X} \pm \mathbf{S S}$ & Min-Maks \\
\hline Duyarlilık Alg1s1 & $7.99 \pm 3.88$ & $3-15$ \\
\hline Ciddiyet Algis1 & $17.04 \pm 8.74$ & $6-30$ \\
\hline Sağlık Motivasyonu Algısı & $17.52 \pm 5.28$ & $5-25$ \\
\hline Mamografi Yarar Algisi & $17.31 \pm 5.34$ & $5-25$ \\
\hline Mamografi Engel Algisi & $26.83 \pm 9.87$ & $11-55$ \\
\hline Mamografi Yeterlilik Ölçeği & $33.03 \pm 9.22$ & $10-50$ \\
\hline
\end{tabular}


Çalışmaya katılan kadınların Meme Kanseri Taramalarında Sağlık İnanç Modeli Ölçeği Alt Boyut ve Mamografi Yeterlilik Ölçeği puan ortalamaları Tablo 3'te yer almaktadır. Katılımcıların meme kanseri duyarlılık algısı puan ortalamas1 $7.99 \pm 3.88$, ciddiyet alg1s1 puan ortalaması $17.04 \pm 8.74$, sağlık motivasyonu alg1s1 puan ortalamas1 $17.52 \pm 5.28$, mamografi yarar alg1s1 puan ortalamasi $17.31 \pm 5.34$ ve mamografi engel alg1s1 puan ortalamas1 $26.83 \pm 9.87$ 'dir. Katılımciların mamografi yeterlilik ölçeği puan ortalaması $33.03 \pm 9.22$ 'dir.

Tablo 4. Katılımcıların meme kanseri taramalarında Sağlık İnanç Modeli Ölçeği alt boyutları ve Mamografi Yeterlilik Ölçeği'ne göre mamografi yaptırma durumları

\begin{tabular}{|c|c|c|c|c|}
\hline \multirow{2}{*}{ Ölçekler } & Mamografi yaptıran & Mamografi yaptırmayan & \multirow{2}{*}{$\mathbf{t}$} & \multirow{2}{*}{$\mathbf{p}$} \\
\hline & $\mathbf{X} \pm \mathbf{S S}$ & $\mathbf{X} \pm \mathbf{S S}$ & & \\
\hline \multicolumn{5}{|l|}{$\begin{array}{l}\text { Meme Kanseri } \\
\text { Taramalarında Sağlık İnanç } \\
\text { Modeli Ölçeği alt boyutları }\end{array}$} \\
\hline Duyarlılık Algisı & $11.44 \pm 3.38$ & $6.75 \pm 3.42$ & $\begin{array}{l}11.9 \\
1\end{array}$ & 0.000 \\
\hline Ciddiyet Alg1sı & $24.73 \pm 5.62$ & $14.30 \pm 7.98$ & $\begin{array}{l}14.2 \\
0\end{array}$ & 0.000 \\
\hline Sağlık Motivasyonu Algısı & $20.84 \pm 4.04$ & $16.33 \pm 5.16$ & 8.89 & 0.000 \\
\hline Mamografi Yarar Algisi & $21.14 \pm 4.29$ & $15.94 \pm 5.00$ & 9.99 & 0.000 \\
\hline Mamografi Engel Algisi & $18.61 \pm 9.86$ & $29.76 \pm 8.06$ & -11.22 & 0.000 \\
\hline Mamografi Yeterlilik Ölçeği & $40.21 \pm 8.50$ & $30.47 \pm 8.05$ & $\begin{array}{l}10.2 \\
8\end{array}$ & 0.000 \\
\hline
\end{tabular}

Çalışmaya katılan kadınların Sağlık İnanç Modeli Ölçeği alt boyutları ve Mamografi Yeterlilik Ölçeği puan ortalamalarına göre mamografi yaptırma durumları Tablo 4'te yer almaktadır. Kadınların duyarlılık, ciddiyet, motivasyon, mamografi yarar, mamografi engel ve mamografi yeterlilik algiları ile mamografi yaptırma durumları arasında istatistiksel olarak anlamlı fark saptanmıştır $(\mathrm{p}=0.000)$.

Tablo 5. Kadınların mamografi yaptırma durumları ile bazı değişkenlerin analizi*

\begin{tabular}{|c|c|c|c|c|c|c|c|}
\hline \multirow[b]{2}{*}{ Değişkenler } & \multirow[b]{2}{*}{$\boldsymbol{\beta}$} & \multirow[b]{2}{*}{$\mathbf{S E}^{\mathbf{a}}$} & \multirow[b]{2}{*}{$d f^{b}$} & \multirow[b]{2}{*}{$\mathbf{p}$} & \multirow[b]{2}{*}{$\mathbf{O R}^{\mathrm{c}}$} & \multicolumn{2}{|c|}{$\% 95 \mathrm{CI}$} \\
\hline & & & & & & Alt sinir & Üst sınır \\
\hline Yaş & -0.667 & 0.407 & 1 & 0.101 & 0.513 & 0.231 & 1.139 \\
\hline Ĕgitim & 1.634 & 0.399 & 1 & 0.000 & 5.125 & 2.344 & 11.206 \\
\hline Sosyal güvence & -1.563 & 1.186 & 1 & 0.188 & 0.210 & 0.020 & 2.142 \\
\hline Duyarlılık Alg1sı & 0.132 & 0.068 & 1 & 0.051 & 1.141 & 1.000 & 1.303 \\
\hline Ciddiyet Alg1sı & 0.035 & 0.041 & 1 & 0.389 & 1.036 & 0.956 & 1.123 \\
\hline Sağlık Motivasyonu & -0.161 & 0.075 & 1 & 0.032 & 0.852 & 0.735 & 0.986 \\
\hline Yarar Alg1si & 0.122 & 0.063 & 1 & 0.050 & 1.130 & 1.000 & 1.278 \\
\hline Engel Alg1s1 & -0.080 & 0.023 & 1 & 0.000 & 0.923 & 0.883 & 0.965 \\
\hline Yeterlilik Alg1sı & 0.042 & 0.027 & 1 & 0.113 & 1.043 & 0.990 & 1.099 \\
\hline
\end{tabular}

*Lojistik regresyon analizi, ${ }^{\mathrm{a}}$ Standart Hata, ${ }^{\mathrm{b}}$ Serbestlik derecesi, ${ }^{\mathrm{c}}$ Odd's Ratio

Çalışmada kadınların mamografi yaptırma durumu ile istatistiksel olarak anlamlılık gösteren bağımsız değişkenlerin lojistik regresyon analizi Tablo 5'te yer almaktadır. Kadınların mamografi davranışı gösterme oranları; eğitim düzeyinin artması ile 5.12 kat, sağlık motivasyonu algısının bir birim artması ile 0.85 kat, mamografi engel algısındaki bir birimlik azalma ile 0.92 kat artmaktadır.

\section{TARTIŞMA}

Yoksul kadınlarda mamografi davranışlarının değerlendirildiği bu çalışmada düzenli mamografi yaptıran kadınların oranı düşük olarak saptanmıştır
(\%26.3). Yoksulluğun sağlık üzerindeki olumsuz etkisi sağlığı koruma ve geliştirme davranışlarında da görülmektedir. Literatürde bu bulgulara benzer olarak kadınların mamografi yaptırma oranlarının düşük olduğu belirtilmektedir. Tahran'da 40 yaş ve üzeri kadınlarda yapılan bir çalışmada kadınların \%42.1'inin mamografi yaptırdığı ve gelir düzeyinin mamografi davranışı göstermede bir yordayıcı olduğu saptanmıştır (Rezaeimanesh ve ark., 2021). Tennessee'de Afrika kökenli Amerikalı 40 yaş üstü 334 yoksul kadınlarda yapılan çalışmada \%73.6'sının mamografi çektirmediği saptanmıştır (Patel ve ark., 2014). Benzer şekilde Donnelly ve arkadaşları (2013) kadınların sadece 
\%26.9'unun mamografi yaptırdığını saptamışlardır. Türkiye'de yapılan çalışmalarda da kadınların mamografi yaptırma davranışlarının yetersiz olduğu belirtilmektedir. Ersin ve arkadaşlarının (2015) çalışmasında kadınların \%34.7'sinin mamografi yaptırdığı saptanmıştır. Yarı kentsel bir bölgede 40 yaş üzerindeki kadınlarda yapılan çalışmada ise mamografi yaptırma oranı \%11.3 olarak belirlenmiştir (Selçuk, Avcı, Dündar ve Mercan, 2020). Literatürde kadınların meme kanseri erken tanı davranışlarında bulunmasında en önemli faktörlerin; meme kanseri ve mamografi ile ilgili eğitim programlarına katılma ve sağlık bilincinin yeterli düzeyde olması belirtilmektedir (Ersin ve Bahar, 2012; Gençtürk, 2013). Bu çalışmada kadınların çoğunluğunun eğitim seviyesi ilkokul altı olması kadınların meme kanseri erken tanısı ve mamografiye yönelik bilgiye ulaşma konusunda kısıtllilılar yaşayabileceğini düşündürmektedir. Ayrıca yoksul kadınlar mamografi gibi tarama davranışlarını düşük öncelikli olarak algılayabilmekte ve bu durum davranışın oluşumunu engelleyebilmektedir.

Çalışmaya katılan kadınların yaş gruplarına göre mamografi yaptırma durumları arasında istatistiksel olarak anlamlı fark saptanmış olup, bu farklılığın 40-49 yaş grubundan kaynaklandığı belirlenmiştir. Bu bulguya zit olarak Norouznia ve Aydoğdu (2019), yaptıkları çalışmada 40 yaş ve üzeri kadınların mamografi yaptırma oranının \%22.8 olduğunu, Rezaeimanesh ve arkadaşları (2018), 61 yaş ve üstü kadınların kanser taramalarında uyumlarının 40-45 yaş grubu kadınlara göre daha iyi olduğunu saptamışlardır. Hastalık Kontrol ve Korunma Merkezi'nin (CDC) (2005) meme kanseri taramaları ve sosyo-ekonomik statü isimli 35 metropolde yaptıkları araştırmada 40-49 yaş grubunda olan kadınların daha yaşlı bireylere oranla son 2 yılda daha az mamografi tarama davranışı gösterdiğini saptamıştır. Patel ve arkadaşları (2014) yoksul Afrika kökenli Amerikalı kadınlarda yaptıkları çalışmada da 40-64 yaş grubunda olan kadınların 65 yaş ve üzerinde olanlara göre daha fazla mamografi taramasına katıldıklarını belirtmişlerdir. $\mathrm{Bu}$ çalışmada 40-49 yaş grubunda olan kadınların mamografi çektirme oranlarının daha yüksek olduğu görülmektedir. $\mathrm{Bu}$ durum genç kadınların teknoloji kullanımı ile bilgiye ulaşma, sağlık kuruluşlarından randevu alabilme gibi konularda yaşlı bireylere göre daha aktif olabilmelerinden kaynaklanabilmektedir.

Literatürde eğitim seviyesinin artması erken tanı davranışlarını olumlu yönde etkileyen bir faktör olarak gösterilmektedir. Yapılan bir çalışmada; üniversite mezunu olan kadınların lise mezunu olan kadınlara oranla daha yüksek mamografi yaptırma oranlarına sahip olduğu belirtilmektedir (CDC, 2005). Kadınların eğitim, gelir gibi sosyo-demografik özellikleri meme kanserinde taramalara katılmalarını bilişsel faktörler üzerinden etkileyebilmektedir. Eğitim ve gelir düzeyi arttıkça, bireylerin meme kanserine ve erken tanısına yönelik algıları da değişerek davranış gösterme oranlarını olumlu yönde etkilemektedir.
Patel ve arkadaşları (2014) yoksul kadınlarda medeni durumun mamografi yaptırma üzerine etkisinin olduğunu, evli olan kadınların bekar olan kadınlara göre daha yüksek oranda tarama davranışı gösterdiğini belirtmiştir. Benzer şekilde yapılan bir diğer çalışmada bekar olan kadınların evli olan kadınlara göre meme kanseri tarama davranışı gösterme oranları daha düşük olarak saptanmıştır (CDC, 2005). Literatürde evli olan kadınların daha fazla tarama davranışlarında bulunma nedenleri arasında eş desteği gösterilmekle birlikte, bu çalışmada medeni durumun etkisinin olmaması yoksul olmaları ile açıklanabilmektedir.

CDC (2005) çalışmasında sosyal güvencenin olmasının tarama davranışlarında artışa neden olduğunu belirtmiştir. Türkiye'de meme kanseri ulusal tarama standartlarına göre kadınlara KETEM'lerde sunulan erken tanı hizmetleri (mamografi) ücretsiz olarak karşılanmakta ancak ikinci basamak sağlık kuruluşlarında verilen hizmetler sosyal güvencesi olmayanlar için ücretli olarak verilmektedir. Bu durum sosyal güvencesi olan ve olmayan kadınlar arasında mamografi davranışı gösterme açısından farklılık oluşturmayacağını düşündürse de özellikle yoksul kadınların ücretsiz verilen hizmetlere yönelik yeterli bilgisinin olmaması çalışma sonuçlarında bu farklılığın ortaya çıkmasına neden olduğunu düşündürmektedir.

Katılımcıların meme kanseri duyarlılık algısı puan ortalamas1 7.99 \pm 3.88 (min. 3-max. 15) ortalama puanın üzerinde saptanmış olup mamografi yaptırma davranışı arasında anlamlı fark saptanmıştır. Yapılan çalışmalarda kadınların meme kanseri duyarlılık alg1si puan ortalamalarının $\quad 6.74 \pm 3.25$ ile $12.99 \pm 3.07$ arasında değişim gösterdiği belirtilmektedir (Aydoğdu, 2012; Güney, 2009; Lee-Lin ve ark., 2007). Duyarlılık algısının kadınların mamografiye yönelik davranışlarında etkisinin olmadığını gösteren çalışmalar da bulunmaktadır (Darvishpour, Vajari ve Noroozi, 2018). Duyarlılık alg1sı bireylerin meme kanseri olma ihtimallerine yönelik olarak kendilerini ne kadar riskli algıladıklarını gösteren bir değişkendir. Duyarlılık algısı yüksek olan bireyler meme kanseri olma ihtimallerinin yüksek olacağına inandıkları için tarama davranışlarını daha fazla gösterebilmektedir.

Kadınların Meme Kanseri Taramalarında Sağlık İnanç Modeli Ölçeği ciddiyet algısı alt boyutu puan ortalamalarının $17.04 \pm 8.74$ (min. 6-max. 30) olduğu ve meme kanseri ciddiyet algısının mamografi yaptırmaya etkisinde anlamlı fark olduğu saptanmıştır (Tablo 4). Literatürde kadınların meme kanseri ciddiyet algısı puan ortalamaları $20.78 \pm 5.12$ ile $23.91 \pm 4.91$ arasında değişmektedir (Güney, 2009; Karabaş, 2013). Ciddiyet algisı bireyin meme kanserini ciddi bir hastalık olarak algılamasına yönelik inancıdır. Meme kanserinin ciddi bir hastalık olduğunu algılamış ve meme kanserini kendisi için bir tehdit olarak gören kadınlar benzer sosyo-demografik özellikteki kadınlara göre daha fazla mamografi yaptırma eğiliminde olabilmektedir. Katılımcıların sağlık motivasyon alt boyut puan ortalamaları $17.52 \pm 5.28^{\prime}$ dir (min. 5-max. 25) ve sağlık motivasyonunun mamografi yaptırmaya etkisi 
incelendiğinde istatistiksel olarak anlamlı fark saptanmıştır (Tablo 4). Sağlık motivasyonunda bir birimlik artış mamografi yaptırma oranında 0.85 kat artışa neden olmaktadır. Aydoğdu (2012) yoksul kadınlar üzerinde yaptığı deneysel çalışmada kadınların sağlık motivasyonu alg1 puanlarının girişim öncesi deney grubunda 20.94 \pm 4.03 , kontrol grubunda $19.62 \pm 3.27$ olduğunu saptamıştır. Literatürde sağlık motivasyonunun yoksul kadınların erken tanı davranışlarına etkisini inceleyen çalışmaya ulaşılamamıştır ancak yoksul olmayan kadınlarda yapılan çalışmalarda sağlık motivasyonunun meme kanseri erken tanı davranışlarına olumlu yönde etkisi olduğu ve uygulanan girişimler ile kadınların motivasyon algısının arttırıldığı saptanmıştır (Seçginli, 2007).

Kadınların mamografi yarar alt boyutu puan ortalamalar1 17.31 \pm 5.34 (min.5- max. 25) olup mamografi yaptırmaya etkisi incelendiğinde istatistiksel olarak anlamlı fark saptanmıştır (Tablo 4). Literatürde yoksul kadınlar ile yapılan çalışmalar sınırlı olmakla birlikte, yoksul kadınlar üzerinde yapılan bir çalışmada kadınların mamografi yarar alt boyutu puan ortalamaları 19.84 \pm 3.66 saptanmıştır (Aydoğdu, 2012). Sosyoekonomik durumu orta düzey olan kadınlarda ise mamografi yarar algısı puan ortalamaları 18.88 \pm 3.90 ile 23.05 \pm 3.31 arasında değişim göstermektedir (Forrest ve Mandelblatt, 2002; Güney, 2009; Lee-Lin ve ark., 2007). Bu çalışmada kadınların mamografi yarar algısı literatürde belirtilen ortalamaların altındadır. Bu durum kadınların mamografiye yönelik acı hissetme, meme kanserine neden olması, mamografi yapılırken çok fazla radyasyona maruz kalma gibi düşünceye sahip olabileceklerini düşündürmektedir.

Kadınların mamografi engel alt boyut puan ortalamaları 26.83 \pm 9.87 (min.11-max.55) olup, mamografi yaptırmaya etkisi incelendiğinde istatistiksel olarak anlamlı fark saptanmıştır (Tablo 4). Kadınlarda engel algısının azalması mamografi yaptırma oranını 0.92 kat arttırmaktadır. Literatürde kadınların mamografi engel algısı puan ortalamaları $16.59 \pm 3.25$ ile $37.53 \pm 10.24$ arasında değişim göstermektedir (Güney, 2009; Lee-Lin ve ark., 2007). Aydoğdu (2012) yaptığı çalışmada yoksul kadınların mamografi engel algisı puan ortalamalarının deney grubunda $28.08 \pm 8.63$, kontrol grubunda $31.18 \pm 6.91$ olduğunu belirtmiştir. Darvishpour ve arkadaşları (2018) algılanan engel puanında yalnızca bir puanlık artışla mamografi yaptırma olasılığının -0.146 kat düştüğünü saptamıştır. $\mathrm{Bu}$ çalışmada kadınların yoksul olması ve erken tanı çalışmalarında sağlık hizmetlerinin kullanımı konusunda yeterli bilgiye sahip olmaması engel algısının artarak mamografi yaptırmayı olumsuz olarak etkilemiş olabilir.

Katılımcıların Mamografi Yeterlilik Ölçeği puan ortalamaları 33.03 \pm 9.22 (min. 10-max. 50) olup yeterlilik algısının mamografi yaptırmaya etkisi incelendiğinde yeterlilik algısı yüksek olan kadınlar ile olmayan kadınlar arasında istatistiksel olarak anlamlı fark saptanmıştır (Tablo 4). Yapılan bir çalışmada kadınların mamografi özetkililik puan ortalamaları 31.44 \pm 13.44 olarak belirtilmiştir (Ersin, Gözükara, Polat, Erçetin ve Bozkurt, 2015). Rezaeimanesh ve arkadaşları (2018) öz etkililik algısı yüksek olan kadınlarda mamografi davranışı gösterme oranının, öz etkililiği düşük olan kadınlara göre 1.93 kat daha fazla olduğunu saptamıştır. Yeterlilik algısı bireylerin bir davranışı gerçekleştirebilmelerine yönelik kendilerine olan inançları, davranışı başarabileceklerine olan algılarını tanımlamaktadır. Bireylerin geçmiş deneyimleri yeterlilik algılarını etkileyerek davranış oluşumunda etkili olabilmektedir.

\section{SONUÇ}

$\mathrm{Bu}$ çalışma sonucunda; okuryazar olmayan kadınların mamografi yaptırma oranları düşük, 40-49 yaş arasında mamografi yaptırma oranının fazla olduğu, sosyal güvencenin olması mamografi yaptırma davranışını arttırdığı, Meme Kanseri Taramalarında Sağlık İnanç Modeli Ölçeği alt boyutları ve Mamografi Yeterlilik Ölçeği puan ortalamalarına göre mamografi duyarlılık, ciddiyet, sağlık motivasyonu, yarar, engel, yeterlilik algısı yüksek olanların mamografi yaptırma oranının fazla olduğu, eğitim durumlarına göre mamografi yaptırma durumları incelendiğinde; yapılan lojistik regresyon analizinde; eğitim seviyesinin artmasının mamografi yaptırma oranını 5.12 kat arttırdığ saptanmıştır. Bu sonuçlar doğrultusunda;

- Özellikle okuma yazması olmayan yoksul kadınların Aile Sağlığı Merkezleri'ne yönlendirilmesi ve burada halk sağlığ 1 hemşireleri tarafından izlenmesi,

- Kadınların sağlık motivasyonlarının mamografi yaptırma üzerine etkisi nedeniyle hemşirelerin; toplumda lider konumundaki bireyler ve yerel yönetimler ile iş birliği içerisinde erken tanı çalışmalarını yürütmesi,

- Kadınların meme kanseri engel algısının azaltılması için meme kanseri erken tanı hizmetlerini ücretsiz olarak nereden alabilecekleri konusunda yoksul kadınlara danışmanlık yapılması,

- Kadınların meme kanseri duyarlılık, ciddiyet algısı, sağlık motivasyonu, mamografi yarar, mamografi engel algıları ve mamografi yeterlilik algıları erken tanı davranışını olumlu yönde etkilediğinden bu algıları arttırmaya yönelik hemşirelik girişimlerinin planlanarak uygulanması önerilmektedir.

\section{Çıkar Çatışması}

Yazarlar, bu makalenin araştırılması, yazarlığı ve/veya yayınlanması ile ilgili olarak herhangi bir potansiyel çıkar çatışması beyan etmemiştir.

\section{Yazar Katkıları}

Plan, tasarım: NGA; Gereç, yöntem ve veri toplama: NGA, SGD; Analiz ve yorum: NGA; Yazım ve eleştirel değerlendirme: NGA, SGD. 


\section{KAYNAKLAR}

Açıkgöz, A., Çehreli, R., \& Ellidokuz, H. (2015). Hastanede çalışan kadınların meme kanseri konusunda erken tanı yöntemlerine yönelik bilgi ve davranışlarının belirlenmesi, uygulanan planlı eğitimin etkinliğinin incelenmesi. Journal of Breast Health, 11, 31-8.

Aydoğdu, N.G. (2012). Sağlığı geliştirme modelleri ile yapılan hemşirelik girişimlerinin yoksul kadınların meme ve serviks kanserine yönelik erken tanı davranışlarına etkisi. Sağlık Bilimleri Enstitüsü, Dokuz Eylül Üniversitesi, Doktora Tezi, İzmir.

CDC MMWR Morbidity and Mortality Weekly Report (2005). Breast cancer screening and socioeconomic status-35 metropolitan areas, 2000 and 2002. 54 (39).https://www.cdc.gov/mmwr/PDF/wk/mm5439.pdf Erişim tarihi:02.07.2019

Champion, V., Skinner, C.S., \& Menon, U. (2005). Development of a self efficacy scale for mammography. Research in Nursing \& Health, 28, 329-336.

Darvishpour, A., Vajari, S.M., \& Noroozi, S. (2018). Can Health Belief Model predict breast cancer screening behaviors? Public Health, 6(5), 949-953.

Donnelly, T.T., Al-Khater, A, Al Bader, S.B., Al- Kuwari, M.G., Al-Meer, N., Malik, et al. (2013). Beliefs and attitudes about breast cancer and screening practice among arab women living in Qatar: A cross-sectional study. BMC Women's Health, 13(49), 2-16.

Ersin, F., Bahar, Z. (2012). Sağlığı geliştirme modelleri'nin meme kanseri erken tanı davranışlarına etkisi: Bir literatür derlemesi. Dokuz Eylül Üniversitesi Hemşirelik Yüksekokulu Elektronik Dergisi, 5(1), 28-38.

Ersin, F., Gözükara, F., Polat, P., Erçetin, G., \& Bozkurt, M.E. (2015). Determining the health beliefs and breast cancer fear levels of women regarding mammography. Turkish Journal Medical Sciences, 45, 775-781.

Forrest, C.B., \& Mandelblatt, J. (2002). Adherence of lowincome women to cancer screening recommendations the roles of primary care, health insurance and HMOs. Journal of General Internal Medicine, 17(2), 144-154.

Gençtürk, N. (2013). Kadın sağlık profesyonellerinin meme kanseri erken tanı yöntemlerini bilme ve uygulama durumları. Meme Sa ̌̆llğgl Dergisi, 9, 5-9.

Global Cancer Observatory (Globocan), (2020). International agancy for research on cancer, Global Cancer Fact Sheet Erişim:24.09.2021.

https://gco.iarc.fr/today/data/factsheets/cancers/20Breast-fact-sheet.pdf

Gözüm, S., Karayurt, Ö., \& Aydın, İ. (2004). Meme kanseri taramalarında champion'un sağlık inanç modeli ölçeğinin türkçe uyarlamalarına ilişkin sonuçlar. Hemşirelikte Araştırma Geliştirme Dergisi, 6(1), 71-85.

Güney, E. (2009). İzmir'de bir fabrikada çalışan kadınların sağlık inançları ile sosyo demografik özelliklerinin meme kanseri erken tanı davranışlarına etkisi. Sağlık Bilimleri Enstitüsü, Dokuz Eylül Üniversitesi, Yüksek Lisans Tezi, İzmir.

Güzel, N., \& Bayraktar, N. (2019). Kadınların meme kanserinin erken tanısına yönelik farkındalıklarının ve uygulamalarının belirlenmesi. Hacettepe Üniversitesi Hemşirelik Fakültesi Dergisi, 6(2), 101-110.

Karabaş, S. (2013). Kadın öğretim elemanlarının meme kanserine bakışı ve kanser korkusunun incelenmesi. Sağlık Bilimleri Enstitüsü, Gaziantep Üniversitesi, Yüksek Lisans Tezi, Gaziantep.
Kocabacak, S. (2014). Kadın yoksulluğu ve kadın sağlığ1 üzerine yansımaları. Sosyal Güvence Dergisi, 6, 135161.

Lee-Lin, F., Menon, U., Pett, M., Nail, L., Lee, S., \& Mooney, K. (2007). Breast cancer belief and mammography screening practices among Chinese American immigrants. JOGNN Clinical Research, 36(3), 212- 221.

Gathirua-Mwangi ve ark. (2018). Factors associated with adherence to mammography screening among insured women differ by income levels. Women's Health Issue, 28(5), 462-469.

Norouzni, S., \& Aydoğdu, G.N. (2019). The effect of breast cancer fear on early detection behaviors of women. International Journal of Caring Sciences, May-August, 12(2), 649-657.

Patel, K., Kanu, M., Liu, J., Brea, B., Brown, E., Williams, E., et al. (2014). Factors influencing breast cancer screening in low-1ncome african americans in tennessee. Journal of Community Health, 39(5): 943-950.

Rezaeimanesh, M., ve ark. (2021). Determinants of mammography screening in Tehranian women in 2018 based on the health belief model: A cross-sectional study. Journal of Education and Health Promotion, 10(119), 1-9.

Sağlık Bakanlığı. Türkiye Halk Sağlığı Kurumu. (2018). Meme kanseri tarama programı ulusal standartları. Erişim:11.11.2019. http://thsk.saglik.gov.tr/2013-10-0111-00-51/halk-sagligina-yonelik-bilgiler/424-memekaner-tarama-standartlari.html.

Selçuk, K.T., Avcı, D., Dündar, G.Y., \& Mercan, Y. (2020). Breast cancer screening behaviors in women aged 40 years and over in a semi-urban region in Turkey: relationships with health beliefs. Healthcare, 8(171), 110 .

Seçginli, S. (2007). Meme kanserinde erken tanıya yönelik sağlığ geliştirme programının tarama davranışlarına etkisi. Sağlık Bilimleri Enstitüsü, İstanbul Üniversitesi, Doktora Tezi, İstanbul.

Seçginli, S. (2012). Mammography self-efficacy scale and breast cancer fear scale psychometric testing of the turkish versions. Cancer Nursing, 35(5), 365-373.

Subramanian, P., Oranye, N., Masri, A., Taib N.A.M., \& Ahmad, N. (2013). Breast cancer knowledge and screening behavior among women with a positive family history. Asian Pacific Journal of Cancer Prevention, 14(11), 6783-6790.

TC. Sağlık Bakanlığ1 Halk Sağlı̆̆1 Genel Müdürlüğü, (2019). Türkiye kanser istatistikleri, 2016. Ankara, 2019. Erişim:20.10.2019. https://hsgm.saglik.gov.tr/depo/birimler/kanserdb/istatistik/Trkiye_Kanser_statistikleri_2016.pdf

Vang, S., Margolies, L.R., \& Jandorf, L. (2018). Mobile mammography participation among medically underserved women: a systematic review. Preventing Chronic Disease, 15:E140. https://doi.org/10.5888/pcd15.180291. 